\title{
INFORMATIVE, EDUCATIONAL, AND PROMOTIONAL ROLE OF GEOCACHING IN THE REGION
}

\author{
Ewa Pisula
}

https://doi.org//10.20867/tosee.06.42

\begin{abstract}
Purpose - The purpose of this paper is to discuss the potential of geocaching as an informative, educational, and promotional tool that can be implemented and managed in a particular area. This paper concentrates on the features of the game and the potential benefits of geocaching for the region. The article also explains the reason why geocaching can be treated as an attractive tool of regional communication and promotion.

Methodology - Desk research method and own research including semi-structured interviews among Officers of Polish Marshal's Offices (14 out of 16 in Poland) were applied to achieve the paper's purpose. In addition, the data obtained from the websites: www.geocaching.pl and www.geocaching.com was analysed as a source for market information. Findings - Findings from the literature review show that players expect geocaching to play an informative, educational, and promotional role. Geocaching is perceived as an attractive tool to showcase the region. Findings from interviews show that regional Officers treat geocaching as a modern tool that can be used to build the region's image and present its values. Contribution - This article proved that geocaching could become a useful and an attractive informative, educational, and promotional tool for regions. Since this kind of game is not commonly used by regional managers in Poland, it is important to analyse its possibilities. As such, this paper is of value to region management seeking solutions to present and make the region more recognizable.
\end{abstract}

Keywords: geocaching, region information, education, region recognition, region promotion.

\section{INTRODUCTION}

Geocaching is a location-based game, in which the goal is to hide and seek caches. The caches are created in various places thus this game encourages players to explore and experience the region (Telaar, Krüger and Schöning 2014). Geocaching is perceived as an attractive tool to present the region, where players can learn about history, culture, and tradition of a particular place. As a result of their participation in the game, players might change the perception of the site where it takes place.

The game is co-created which means it is developed by players themselves (Telaar, Krüger and Schöning 2014; Matherson et al. 2008). Therefore, regional offers might be created by players, who choose which place and what attractions they want to present to others. Thanks to players and the opportunity they take to create the game, caches are hidden in various locations and this way a particular region becomes more and more attractive to be discovered (Neustaedter, Tang and Judge 2013). In addition, caches 
ToSEE - Tourism in Southern and Eastern Europe, Vol. 6, pp. 623-635, 2021.

E. Pisula: INFORMATIVE, EDUCATIONAL, AND PROMOTIONAL ROLE OF GEOCACHING ...

contain descriptions of a particular place, thus the game can be an attractive tool to inform about regional values, culture, or history. As such, geocaching offers opportunities to raise awareness of the region, to communicate its values, and to present its assets. Geocaching is a way to make the location recognizable (Ihamäki 2012; Ihamäki 2015; Gram-Hansen 2009).

Geocaching is a modern and new game, but it is becoming more and more popular all over the world. Currently, caches are hidden in 191 countries (Groundspeak, Fast facts 2021) - as of March 2021 there were 3273856 caches to seek in the world, and they were located in every continent (Groundspeak, The world 2021). In Poland, this game is also very popular - as of March 2021 there were 52883 active caches, as indicated in the table; the number of caches has been increasing (see Table 1) thus the number of places to visit (including potential information about each place) has been also growing. There is also a noticeable increase in the number of participants (see Table 1), so geocaching attracts the attention of the Polish regional authorities.

Table 1: Number of active caches and players in each month (data was collected from June 2019 to March 2021)

\begin{tabular}{lrr}
\hline & Number of active caches & Players \\
\hline June 2019 & 47828 & 175997 \\
July 2019 & 48032 & 181037 \\
August 2019 & 48501 & 183801 \\
September 2019 & 49037 & 185971 \\
October 2019 & 49078 & 187887 \\
November 2019 & 48918 & 189075 \\
December 2019 & 48781 & 189914 \\
January 2020 & 47317 & 191100 \\
February 2020 & 47013 & 192379 \\
March 2020 & 47653 & 193599 \\
April 2020 & 49525 & 194256 \\
May 2020 & 50896 & 196791 \\
June 2020 & 51663 & 199055 \\
July 2020 & 52097 & 202736 \\
August 2020 & 52396 & 206422 \\
September 2020 & 52588 & 209753 \\
October 2020 & 52502 & 211975 \\
November 2020 & 52745 & 213464 \\
December 2020 & 214292 \\
January 2021 & 52254 & 215363 \\
February 2021 & 52383 & 216105 \\
March 2021 & 52409 & 217718 \\
\hline
\end{tabular}

Source: Groundspeak, Geocaching, Poland

The purpose of this paper is therefore to discuss the potential of geocaching as an informative, educational, and promotional tool that can be implemented and managed in the particular area. Desk research method and own research results were applied to achieve the paper's purpose. Literature review was therefore performed where the existing research results were analysed to diagnose the knowledge in a subject area. 
ToSEE - Tourism in Southern and Eastern Europe, Vol. 6, pp. 623-635, 2021.

E. Pisula: INFORMATIVE, EDUCATIONAL, AND PROMOTIONAL ROLE OF GEOCACHING ...

In addition, the data obtained from the websites: www.geocaching.pl and www.geocaching.com was analysed as a source for market information. This article also analyses the research results of previous studies discussing geocaching as a tool used to inform, educate, and make the place more recognizable as well as those discussing the user's perspective. To analyse the potential of the game, individual semi-structured interviews among Officers of Polish Marshal's Offices were conducted (14 out of 16 in Poland), as according to Act on Voivodship Government (1998), the voivodship government is responsible for the region's development and related activities, including promotion of the regional values. The goal of the interviews with representatives responsible for the marketing, branding, promotion strategy of voivodships in Marshal's Offices was to identify the current stage of implementation of geocaching and its potential as a tool of regional communication and promotion. Therefore, it was crucial to analyse the opinions about the game of decision-makers in the regions.

\section{LITERATURE REVIEW}

In XXI century, regions compete against each other to attract citizens, investors, tourists, visitors, and other groups as well as to retain them in the place (Florek 2013). Regions want therefore to become more attractive, and consequently "their goal is to improve the image as attractive and competitive amongst desired target groups in the hope that a positive image will influence individual and institutional decisions" (Boisen, Terlouw and van Gorp 2011, 136).

A region is defined as a group of lands which differ from other areas, characterized by its own customs, features and history (Kuciński 1990). A region can be also defined as an administrative unit, for example: country, region, district, city (Milewski and Meyer 2009). In Poland there are three levels of public administration division, including: 16 voivodeships - also called regions (NUTS 2 according to EU nomenclature), 314 districts and 2477 communes.

Each region is different, with its own history and heritage, values, goals, and ambitions and therefore tells a different story which needs to be communicated with adequate instruments and channels. Among possible solutions, geocaching might be considered as attractive tool to inform, as well as to educate about a place and to promote it. Geocaching is a location-based game which was created in 2000. It is a global game in which players are to seek and hide containers, called geocaches/caches. Caches include "treasure" (for example toys) and logbooks (participants are expected to sign in the logbook after they find the caches). Caches can be created not only in the form of traditional boxes but also the elements of surroundings (e.g. monuments, buildings, statue etc.) may serve as caches. The aim of players who create the cache is to present a particular place, view, monument etc. (Battista et al. 2016).

The aim of the game is therefore to find hidden caches using Global Positioning System (GPS). The idea behind geocaching is that each participant can hide a cache in a particular place. Then the information about the location of the caches (latitude and longitude coordinates) and information about particular places (photos, videos etc.) is published on the website. Other players seek the place where caches were hidden, using 
ToSEE - Tourism in Southern and Eastern Europe, Vol. 6, pp. 623-635, 2021.

E. Pisula: INFORMATIVE, EDUCATIONAL, AND PROMOTIONAL ROLE OF GEOCACHING ...

GPS devices. When the cache is found, the participant is expected to share their experiences on the website (Battista et al. 2016; O'Hara 2008).

Geocaching offers a great opportunity to integrate education (Matherson et al. 2008) with physical activity (Battista et al. 2016), sightseeing, exploring new places, learning about the regional history, culture, customs, and traditions (Matherson et al. 2008). Features of the geocaching such as: information, place, and participation (Neustaedter, Tang and Judge 2013) support this opinion (see Table 2). Firstly, caches' descriptions are related to each location and include information about a place and a particular theme related to each location (Ihamäki 2015; Gram-Hansen 2009; Heljakka and Ihamäki 2017; Neustaedter, Tang and Judge 2013). Although information about the place is published virtually, the players are obligated to look for this place in the real world. This rule of geocaching encourages players to experience and explore the region as well as to build relations with the particular place when they are playing (Liberati 2017). According to Bragg $(2014,11)$ "geocaching offers access to a place-based approach to education through a connection with the environment". Gram-Hansen $(2009,7)$ agreed with this statement claiming that "people would have the opportunity to read the description from behind their computer and maybe gain interest in the area described".

Geocaching offers an opportunity to present unknown and unique places (Telaar, Krüger and Schöning 2014) this is possible thanks to rules and engagement of players. Caches can be hidden in various places and it is up to the geocachers to decide where to hide them. They put caches in places which are important to them but also little known (Bragg 2014). According to O'Hara $(2008,1180)$ "caches are not placed in random hiding places but rather are located in places of natural beauty or significance". Participants may take part in the game as players who create the cache as well as players who seek the cache. Participants can choose which place and what information they want to present to other players (Telaar, Krüger and Schöning 2014). Experience and participation are elements of the game which give the opportunity to explore, interact with, inform, and learn about a region.

\section{Table 2: Features of geocaching - benefits for the region}

\begin{tabular}{|c|c|c|}
\hline Information in the game & Participation & Place \\
\hline $\begin{array}{l}\text { Descriptions of the region are } \\
\text { published on the website (Bragg } \\
\text { 2014) }\end{array}$ & $\begin{array}{l}\text { Geocaching encourages } \\
\text { players to learn about region } \\
\text { (Kapoun 2016) }\end{array}$ & $\begin{array}{l}\text { Geocaching is a tool to explore the } \\
\text { region, get to know new places } \\
\text { better (Telaar, Krüger and } \\
\text { Schöning 2014; O'Hara 2008; } \\
\text { Ihamäki 2014; Falcao, Damasio } \\
\text { and Melo 2014; Heljakka and } \\
\text { Ihamäki 2017; Gram-Hansen 2009) }\end{array}$ \\
\hline $\begin{array}{l}\text { Information is about } \\
\text { monuments, attractions, values, } \\
\text { institutions, restaurants, hotels, } \\
\text { events in the region (Gram- } \\
\text { Hansen 2009; Heljakka and } \\
\text { Ihamäki 2017; Santos et al. } \\
\text { 2012; Boulaire and Hervet } \\
\text { 2012; Neustaedter, Tang and } \\
\text { Judge 2013) }\end{array}$ & $\begin{array}{l}\text { Geocaching is the chance to } \\
\text { learn about history (natural, } \\
\text { local etc.), culture, } \\
\text { ethnography (Telaar, Krüger, } \\
\text { and Schöning 2014; Falcao, } \\
\text { Damasio and Melo 2014; } \\
\text { Ihamäki 2015; Heljakka, } \\
\text { and Ihamäki 2017; Schneider } \\
\text { and Chavez 2011) }\end{array}$ & $\begin{array}{l}\text { Geocaching is a tool to present the } \\
\text { region, places worth seeing, as well } \\
\text { as regional history, heritage, } \\
\text { culture of a particular place (Xu et } \\
\text { al. 2016; O'Hara 2008; } \\
\text { Neustaedter, Tang and Judge 2010; } \\
\text { Schneider and Chavez 2011; } \\
\text { Ihamäki 2015; Gram-Hansen 2009) }\end{array}$ \\
\hline
\end{tabular}


ToSEE - Tourism in Southern and Eastern Europe, Vol. 6, pp. 623-635, 2021.

E. Pisula: INFORMATIVE, EDUCATIONAL, AND PROMOTIONAL ROLE OF GEOCACHING ...

Table 2 (continued)

\begin{tabular}{|c|c|c|}
\hline Information in the game & Participation & Place \\
\hline \multirow[t]{4}{*}{$\begin{array}{l}\text { The information about the } \\
\text { region is available } 24 \text { hours a } \\
\text { day (Cord, Roeßinger, and } \\
\text { Schwartz, 2015) }\end{array}$} & $\begin{array}{l}\text { Thanks to geocaching players } \\
\text { notice elements of } \\
\text { surroundings that they haven't } \\
\text { seen before (Locke et al. } \\
2018 \text { ) }\end{array}$ & $\begin{array}{l}\text { Geocaching gives opportunity to } \\
\text { interact with surroundings (Kapoun } \\
\text { 2016) }\end{array}$ \\
\hline & $\begin{array}{l}\text { Thanks to geocaching players } \\
\text { may experience new things as } \\
\text { well as the region (Schneider } \\
\text { and Chavez 2011) }\end{array}$ & $\begin{array}{l}\text { Caches can be created in various } \\
\text { places (Garney et al. 2016) }\end{array}$ \\
\hline & & $\begin{array}{l}\text { The place is the part of the game } \\
\text { (Neustaedter, Tang and Judge } \\
\text { 2013) }\end{array}$ \\
\hline & & $\begin{array}{l}\text { Geocaching encourages visiting } \\
\text { particular places (Schneider and } \\
\text { Chavez 2010) }\end{array}$ \\
\hline
\end{tabular}

Source: Own elaboration based on literature review

Literature review allowed to develop interview scenario for the study to verify the expectations and opinions about geocaching by regional brand managers.

\section{RESEARCH METHODOLOGY}

The aim of this research was to define how the representatives responsible for branding (or marketing/promotion as they are often treated equivalently) strategy of regions evaluated geocaching as a tool of regional communication and promotion. Semistructured interview was chosen as a research technique which allows to follow the prepared scenario, and the researcher has opportunity to ask additional questions and comments (Adams 2015).

According to Act on Voivodship Government (1998), the voivodship government (Marshal's Office) is responsible for regional development and related activities including promotion of the region's values. As mentioned earlier, Poland is divided into 16 voivodships and therefore the representatives of 16 Marshal's Offices were selected as the population in the survey. The specific representatives were identified through official website information, and all were contacted via e-mail and telephone by the author. Two of 16 representatives of Marshal's Offices didn't agree to take part in the survey, consequently 14 representatives were interviewed. 11 interviews were conducted via telephone (pandemic didn't enable to organize face to face interviews), in three cases respondents agreed to take part in survey on the condition that they could send answers by e-mail. According to Sztumski (1995), while interviewing there is an opportunity to send questions and receive answers in oral or written form. Interviews were carried out between $23^{\text {rd }}$ November 2020 and $12^{\text {th }}$ January 2021. The interview included five general openended questions and four closed-ended questions (see Table 3). 
ToSEE - Tourism in Southern and Eastern Europe, Vol. 6, pp. 623-635, 2021.

E. Pisula: INFORMATIVE, EDUCATIONAL, AND PROMOTIONAL ROLE OF GEOCACHING ...

Table 3: Questions included in the interview scenario

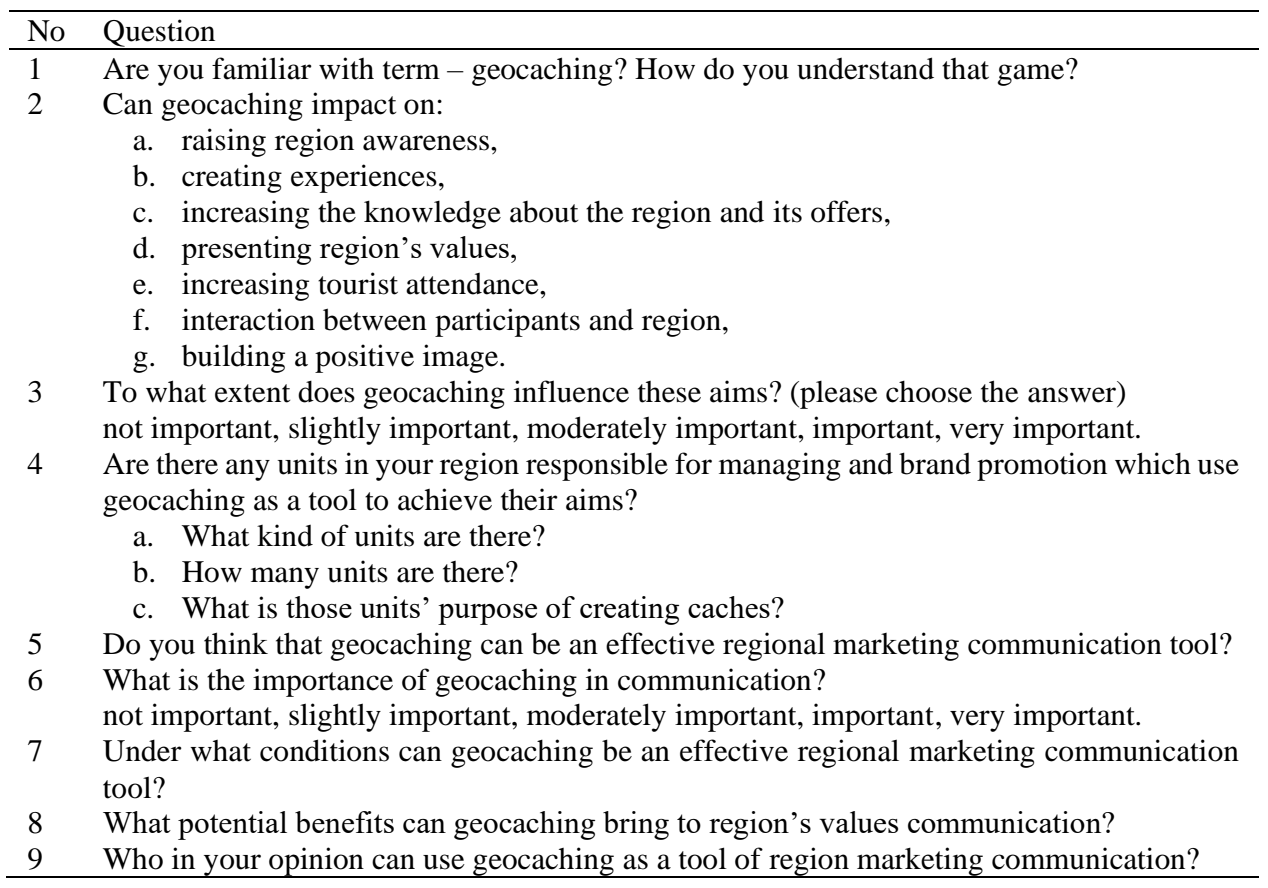

Source: Own elaboration

14 respondents interviewed included: eight Departments' Directors; four Managers of Departments' branch Offices, and two Officers of Departments. The average duration of the interview was about 20 minutes. After interviews and questionnaires had been collected, data was analysed according to the questions described in Table 3.

\section{FINDINGS AND DISCUSSION}

At the beginning of the interviews, the respondents' knowledge about geocaching was examined. 13 respondents were familiar with geocaching while one of them hasn't heard about the game before (R6). Geocaching was described as a modern game (R1), little known (R4, R5, R7, R10) which is created by players who seem to be engaged in regional promotion (R2, R10, R14).

Respondents were asked then for the opinion about geocaching as a tool used to achieve marketing communication goals. Findings from the interviews show that geocaching can be successfully used as a tool to build a positive image of the region (11 out of 14). One of the respondents also admitted that:

geocaching can help build a positive image because when the caches are hidden in a particular place it is possible to present attractiveness and values of that location (R1). 
ToSEE - Tourism in Southern and Eastern Europe, Vol. 6, pp. 623-635, 2021.

E. Pisula: INFORMATIVE, EDUCATIONAL, AND PROMOTIONAL ROLE OF GEOCACHING ...

Similarly, according to respondents' opinions, geocaching seems to be an attractive tool to present region's values (12 out of 14) because: it is an attractive solution to explore the region (R11), seeking the caches encourages players to interact with the region (R3), caches lead players to a particular place and also present the region's attractions, and values (R7, R10, R11), game allows to pay attention to particular place (R11).

Through geocaching players have an opportunity to interact with the region (11 out of 14) and also experience the region by themselves (10 out of 14). According to respondents' opinions geocaching seems to be an attractive tool to increase the participants' knowledge about the place because players get to know regional offers better (10 out of 14$)$.

Since players receive information about the region or suggestions where they should go to seek caches, they are encouraged to find the information and answers by themselves. Therefore, they explore the region by themselves (RI).

Geocaching was described as an attractive tool to educate because of players' involvement, independence while looking for answers, and importantly, willingness to participate (R11) and focus on the game (R3).

Geocaching offers opportunities to raise awareness of the region (R1, R3, R4, R5, R12, R14):

Geocaching can be used to create a region's image and present attractions. Players experience the region, and they get to know the region better $(R I)$.

Geocaching can also increase tourism (R1, R8, R12, R14).

The next question was asked to identify the regional units/organisations responsible for the brand management which used geocaching as a promotional tool. Only in four regions geocaching was applied to promote the region (R1, R3, R4, R7) with the help/cooperation of: Regional Tourist Organizations (R3, R7), Non-governmental organizations (R7), Local Tourist Organizations (R4), Associations responsible for region development and promotion (R3, R4), and External private companies hired to create caches $(\mathrm{R} 1)$.

Respondents were asked about what kind of units could use geocaching to promote a region, and they recommended: local governments (R1, R3, R10); State Forests (R12); Polish Tourist and Sightseeing Society (R10, R13), culture institutions such as museums, castles etc. (R12); The Polish Scouting and Guiding Association (R13).

The next part of the research was to verify the reasons/aims for creating caches by units responsible for region brand management. Respondents named several reasons:

- geocaching allows to present the region, attractions, and interesting places (R1, R3) and also to inform about the fact that many interesting offers are in the neighbourhood (R1),

- geocaching is a promotional tool (R3), 
ToSEE - Tourism in Southern and Eastern Europe, Vol. 6, pp. 623-635, 2021.

E. Pisula: INFORMATIVE, EDUCATIONAL, AND PROMOTIONAL ROLE OF GEOCACHING ...

- geocaching is an informative tool, that allows to send information to particular players, who are interested in a region (R3),

- geocaching is an educational tool used to increase the knowledge about the region (R4, R7),

- geocaching is an attractive solution to engage players to explore the region (R7).

The next part of research was to verify if and when geocaching could be an effective marketing communication tool. All respondents admitted that geocaching could be an effective marketing communication tool as it could be used to present a region and its offers, its values, and attractions. Geocaching gives an opportunity to make a list of attractions, monuments, hotels, restaurants, and what is more, information about a region can be collected in one place (R1). Geocaching can be an effective tool provided some assumptions are met, for example: the caches need to be hidden in an attractive place (R1), and the information included in the caches should be interesting and relate to the region (R11).

According to respondents' opinions, geocaching has potential (R10), as caches present the location as well as inform about a place (R3), thus game can encourage to visit a particular area (R1). In addition, geocaching integrates the virtual world with real one. Players receive information on the website and then they go to the real world to look for the particular place (R3). Geocaching is based on modern technology, caches are presented on the virtual map and thanks to this solution there is an opportunity to present the exact location of the regional attraction, monument, or view etc. (R3, R11). This information published on the website is available for a long time thus as long as the information is available, the information about the region is communicated (R6)

\section{CONCLUSION}

According to the research results, geocaching seems to be attractive tool to promote a region and it can be used as a supporting tool during promotional actions. Geocaching is valuable tool which can help to raise awareness about a place since caches can be created in places which regional managers want to showcase. Geocaching can be considered as a type of technologically assisted hiking and it can also be presented as a new way to explore as well as to make a place, a country, a region, or a city more attractive (Boulaire and Hervet 2012). Geocaching can be promoted as another way to discover and interpret the region (Boulaire and Hervet 2012). These statements were in line with respondents' answers.

Findings from existing research results show that players expect geocaching to play an informative, educational, and promotional role (Telaar, Krüger and Schöning 2014; Rowland 2016; Cord, Roeßinger and Schwartz 2015). Findings from literature review and own research results are juxtaposed and summarised in the Tables 4, 5, 6, according to an informative, educational, and promotional role of the game. In addition, the players' perspective is presented, who realize that when they take part in the game, they are responsible for regional communication (Neustaedter, Tang and Judge 2010). 
ToSEE - Tourism in Southern and Eastern Europe, Vol. 6, pp. 623-635, 2021.

E. Pisula: INFORMATIVE, EDUCATIONAL, AND PROMOTIONAL ROLE OF GEOCACHING ...

According to O'Hara $(2008,1180)$ "geocaching was being used by people as a form of social recommendation about places - a way to explore and discover". The game therefore engages players to promote the region and the players themselves feel responsible for presenting regional values. Those statements are in line with interviews results where according to respondents' answers geocaching is addressed to groups who care about a region and its development and who are focused on its promotion.

Table 4: Findings from literature review and own research verifying informative role of geocaching

\begin{tabular}{|c|c|c|}
\hline $\begin{array}{c}\text { Literature review-players } \\
\text { opinions }\end{array}$ & $\begin{array}{l}\text { Literature analysis about } \\
\text { informative role of geocaching }\end{array}$ & $\begin{array}{l}\text { Respondents' opinions } \\
\text { about informative role of } \\
\text { geocaching }\end{array}$ \\
\hline \multicolumn{3}{|c|}{ Informative role of geocaching } \\
\hline $\begin{array}{l}\text { - The goal of players who } \\
\text { create cache is to present an } \\
\text { attractive place in the } \\
\text { region (Neustaedter, Tang } \\
\text { and Judge 2010). } \\
\text { - Players want to take part in } \\
\text { the game as sender } \\
\text { and receiver of region } \\
\text { information (O'Hara 2008). } \\
\text { - Players like geocaching } \\
\text { because they can inform } \\
\text { about the place } \\
\text { of the game (O’Hara 2008; } \\
\text { Neustaedter, Tang and } \\
\text { Judge, 2010; Schneider } \\
\text { and Chavez 2011). }\end{array}$ & $\begin{array}{l}\text { - Geocaching is a tool } \\
\text { to inform about the region } \\
\text { (Ihamäki 2012). } \\
\text { - Players can create } \\
\text { and communicate regional } \\
\text { offers; players take part in the } \\
\text { game as a sender and receiver } \\
\text { of the information (Ihamäki } \\
\text { 2012; Ihamäki 2015). } \\
\text { - The information is sent at } \\
\text { specific place and time } \\
\text { (O'Hara, 2008; Neustaedter, } \\
\text { Tang and Judge 2013). } \\
\text { - The information about the } \\
\text { region is available a long } \\
\text { time (Neustaedter, Tang and } \\
\text { Judge 2013). }\end{array}$ & $\begin{array}{l}\text { - Geocaching can be used } \\
\text { to inform about region, } \\
\text { history, attractions, } \\
\text { monuments etc. (R5, } \\
\text { R14). } \\
\text { - Geocaching is a } \\
\text { communication tool, via } \\
\text { geocaching the message } \\
\text { about a region is sent to } \\
\text { a receiver (R11). } \\
\text { - Information is available } \\
\text { for a long time (R6). }\end{array}$ \\
\hline
\end{tabular}

Source: Own elaboration based on literature review and interviews 
ToSEE - Tourism in Southern and Eastern Europe, Vol. 6, pp. 623-635, 2021.

E. Pisula: INFORMATIVE, EDUCATIONAL, AND PROMOTIONAL ROLE OF GEOCACHING ...

Table 5: Findings from literature review and own research verifying educational role of geocaching

\begin{tabular}{|c|c|c|}
\hline $\begin{array}{c}\text { Literature review-players } \\
\text { opinions }\end{array}$ & $\begin{array}{c}\text { Literature analysis about } \\
\text { educational role } \\
\text { of geocaching }\end{array}$ & $\begin{array}{l}\text { Respondents' opinions } \\
\text { about educational role } \\
\text { of geocaching }\end{array}$ \\
\hline \multicolumn{3}{|c|}{ Educational role of geocaching } \\
\hline $\begin{array}{l}\text { - Players' aim is to educate } \\
\text { about region (O’Hara 2008; } \\
\text { Schneider and Chavez 2011). } \\
\text { - Players like geocaching } \\
\text { because they can share their } \\
\text { knowledge (O'Hara 2008; } \\
\text { Neustaedter, Tang and Judge } \\
\text { 2010; Schneider and Chavez } \\
\text { 2011). } \\
\text { Geocaching is treated as a } \\
\text { source of knowledge about } \\
\text { the region (Heljakka and } \\
\text { Ihamäki 2017; Falcao, } \\
\text { Damasio and Melo 2014; } \\
\text { Telaar, Krüger and Schöning } \\
\text { 2014). }\end{array}$ & $\begin{array}{l}\text { - Geocaching help to } \\
\text { educate about region } \\
\text { (Ihamäki 2015; Kapoun } \\
\text { 2016). } \\
\text { - Players learn about history, } \\
\text { culture, tradition, values of } \\
\text { the region (Matherson et } \\
\text { al. 2008; Telaar, Krüger } \\
\text { and Schöning 2014; } \\
\text { Falcao, Damasio and Melo } \\
\text { 2014; Heljakka } \\
\text { and Ihamäki 2017). }\end{array}$ & $\begin{array}{l}\text { - Geocaching encourages } \\
\text { to learn about the region } \\
\text { (R4, R5, R14). } \\
\text { - Geocaching can be used } \\
\text { as an educational tool } \\
\text { thus the players get to } \\
\text { know the region better } \\
\text { (R10, R12). } \\
\text { - Geocaching is an } \\
\text { attractive tool to increase } \\
\text { participants' knowledge } \\
\text { about the region (10 out } \\
\text { of 14). }\end{array}$ \\
\hline
\end{tabular}

Source: Own elaboration based on literature review and interviews

Table 6: Findings from literature review and own research verifying promotional role of geocaching

\begin{tabular}{|c|c|c|}
\hline $\begin{array}{c}\text { Literature review-players } \\
\text { opinions }\end{array}$ & $\begin{array}{c}\text { Literature analysis about } \\
\text { promotional role } \\
\text { of geocaching }\end{array}$ & $\begin{array}{c}\text { Respondents' opinions about } \\
\text { promotional role } \\
\text { of geocaching }\end{array}$ \\
\hline \multicolumn{3}{|c|}{ Promotional role of geocaching } \\
\hline $\begin{array}{l}\text { - Players want to present } \\
\text { region and its values } \\
\text { (Ihamäki 2013; } \\
\text { Neustaedter, Tang } \\
\text { and Judge 2013). } \\
\text { Players want to encourage } \\
\text { others to explore region } \\
\text { (Neustaedter, Tang } \\
\text { and Judge 2010). }\end{array}$ & $\begin{array}{l}\text { - Geocaching is an attractive } \\
\text { tool to present values of the } \\
\text { region (Santos et al. 2012; } \\
\text { Matherson et al. 2008). } \\
\text { - Geocaching makes the place } \\
\text { more attractive (Boulaire } \\
\text { and Hervet 2012; Schneider } \\
\text { and Chavez 2011; } \\
\text { Neustaedter, Tang } \\
\text { and Judge 2013). } \\
\text { - Region is the place where } \\
\text { the action of the game takes } \\
\text { place as well as the values, } \\
\text { attractions of the region are } \\
\text { used to create and develop } \\
\text { the game (Neustaedter, } \\
\text { Tang and Judge 2013). }\end{array}$ & $\begin{array}{l}\text { - Geocaching encourages to } \\
\text { explore, visit a particular } \\
\text { place (R2, R4, R5, R14). } \\
\text { - Thanks to geocaching each } \\
\text { place became more and } \\
\text { more interesting (R3). } \\
\text { - Players are more interested } \\
\text { in the region via } \\
\text { geocaching (R3). } \\
\text { - Geocaching promotes } \\
\text { the region (R5, R8). }\end{array}$ \\
\hline
\end{tabular}

Source: Own elaboration based on literature review and interviews 
ToSEE - Tourism in Southern and Eastern Europe, Vol. 6, pp. 623-635, 2021.

E. Pisula: INFORMATIVE, EDUCATIONAL, AND PROMOTIONAL ROLE OF GEOCACHING ...

Literature review and interviews results allow to identify benefits of geocaching for the region brand management:

- via creating caches in a particular place, attractions of the region can be mapped. Thus, there is an opportunity to create a map presenting the region's assets (Neustaedter, Tang and Judge 2013). Players use geocaching to search information about the region and attractions, as such geocaching helps them find particular sites (Schaal and Lude 2015),

- designing caches allows managers to create specific trails presenting local attractions (Boulaire and Hervet 2012),

- since caches include tasks and puzzles related to particular place, it engages participants to learn about region (Telaar, Krüger and Schöning 2014; Falcao, Damasio and Melo 2014),

- participants receive information in real geographical places (Boulaire and Hervet 2012). "The strength of the experience is that the user will actually be physically present in many of the locations mentioned in the geocache information" (GramHansen 2009, 6).

The purpose of this paper was to analyse the potential of geocaching as an informative, educational, and promotional tool for regions. Despite the advantages, regional bodies responsible for promotion of the region in Poland don't use this kind of tool to promote locations very often. They should constantly seek creative solutions to present region's values, and geocaching offers new opportunities to present the region. As the paper argues, the game fulfils three functions: informative, educational, and promotional because the game integrates the place, information about the place and players' participation/engagement that is why the place can be interpreted. Thus, it can be considered that the effect of the game is that participants gain concrete information about region, they get to know the region and also the region is promoted via creating the caches and their participation. Contribution of this paper is that it provides research data confirming that the development of the region, promotion of the region, and region marketing communication can be based on a tool such as geocaching. Results from this paper suggest several implications for region brand managers suggesting that geocaching should be deeply considered as a tool of regional marketing communication. Possible limitations are associated with using geocaching as a regional marketing communication tool in the region because this tool is not used to present region's values in Poland very often. Future research should investigate the conditions for the effectiveness of geocaching in the region's marketing communication based on the opinions of the players. It is important to consider if geocaching could be effective tool to communicate region's information.

\section{REFERENCES}

Adams, C.W. (2015), "Conducting Semi-Structures Interviews", in Newcomer, K.E., Hatry, H.P. and Wholey, J.S. (Ed.), Handbook of Practical Program Evaluation, Fourth, Jossey-Bass, A Wiley Brand, pp. 492-505. https://doi.org/10.1002/9781119171386.ch19

Battista, R.A., Mackenzie S.H., West, S.T. and Son, J.S. (2016), "Is This Exercise? No, It's Geocaching! Exploring Factors Related to Aspects of Geocaching Participation", Journal of Park and Recreation Administration, Vol. 34, No. 2, pp. 30-48. doi: http://dx.doi.org/10.18666/JPRA-2016-V34-12-6495 
ToSEE - Tourism in Southern and Eastern Europe, Vol. 6, pp. 623-635, 2021.

E. Pisula: INFORMATIVE, EDUCATIONAL, AND PROMOTIONAL ROLE OF GEOCACHING ...

Boisen, M., Terlouw, K. and van Gorp, B. (2011), "The selective nature of place branding and the layering of spatial identities", Journal of Place Management and Development, Vol. 4, No. 2, pp. 135-147. doi: 10.1108/17538331111153151

Boisen, M. (2015), "Place branding and non-standard regionalization in Europe", in Zenker, S. and Jocbsen, B.P. (Ed.), Inter-regional place branding: Best practices, challenges and solutions, Springer, Cham, pp. 13-23. doi:10.1007/978-3-319-15329-2_2

Boulaire, C. and Hervet, G. (2012), "New Itinerancy: The Potential of Geocaching for Tourism", International Journal of Management Cases, Vol. 14, No. 4, pp. 210-218. doi:10.5848/APBJ.2012.00099

Bragg, L.A. (2014), "Geocaching: finding mathematics in a global treasure hunt", Australian Primary Mathematics Classroom, Vol. 19, No. 4, pp. 9-14.

Cord, D., Roeßinger, F. and Schwartz, N. (2015), "Geocaching data as an indicator for recreational ecosystem services in urban areas: exploring spatial gradients, preferences and motivations", Landscape and Urban Planning, No. 144, pp. 151-162. doi: 10.1016/j.landurbplan.2015.08.015

Liberati, N. (2017), "Phenomenology Pokemon Go and Other Augmented Reality Games", Human Studies, Vol. 41, No. 4, pp. 211-232 https://doi.org/10.1007/s10746-017-9450-8

Falcao, A.L., Damasio, A.S. and Melo, R. (2014), "Motivations for participating in geocaching activities in Portugal”, Conference: Sport Tourism. New Challenges in a Globalized World, Coimbra, Portugal, pp. 176-184.

Florek, M. (2013), Podstawy marketingu terytorialnego, Wydawnictwo Uniwersytetu Ekonomicznego w Poznaniu, Poznań.

Garney, W.R., Young, A., McLeroy, K.R., Wendel, M.L. and Schudiske, E. (2016), "A Qualitative Examination of Exergame Motivations in Geocaching", Games for Health Journal: Research, Development and Clinical Applications, Vol. 5, No. 1, pp. 34-39. doi: 10.1089/g4h.2015.0025

Glińska, E. (2011), "Sposoby badania wizerunki miejsca”, Samorzad Terytorialny, Vol. 11, pp. 33-44.

Gram-Hansen, L.B. (2009), "Geocaching in a persuasive perspective", Conference: Persuasive Technology, Fourth International Conference, Persuasive 2009, California: Claremont, No. 34, pp. 1-8 https://doi.org/10.1145/1541948.1541993

Groundspeak, Fast facts (2021), viewed 7 March 2021, www.newsroom.geocaching.com/fast-facts.

Groundspeak, n.d., Geocaching, Poland, www.geocaching.pl.

Groundspeak, Statististics (2021), viewed 7 March 2021 www.geocaching.pl/statistics.php?country_id=158.

Groundspeak, The world (2021), viewed 7 March 2021, www.geocaching.com/play/search?ot=4

Heljakka, K. and Ihamäki, P. (2017), "The Sigrid-Secrets Geocaching Trail: Influencing Well-being through a gamified art experience", Conference: GamiFIN 2017, Finland, pp. 71-80.

Ihamäki, P. (2012), "Geocaching: Interactive Communication Channels Around the Game", Eludamos. Journal for Computer Game Culture, Vol. 6, No. 1, pp. 133-152.

Ihamäki, P. (2013), “Geocachers' creative experiences along coastal road in Finland”, International Journal Leisure and Tourism Marketing, Vol. 3, No. 3, pp. 282-299. doi:10.1504/IJLTM.2013.052635

Ihamäki, P. (2014), "GameFlow experience model: Understanding player enjoyment in pervasive adventure geocaching game", International Journal of Wireless and Mobile computing, Vol. 7, No. 6, pp. 536548. doi:10.1504/IJWMC.2014.065605

Ihamäki, P. (2015), "Design the Pori hidden beauties geocaching series: computer-supported collaborative web-based learning and sharing experiences", International Journal Web Based Communities, Vol. 1, No. 2, pp. 131-152. doi:10.1504/IJWBC.2015.068538

Kapoun, P. (2016), "Geolocation Services in Education Outside the Classroom", International Journal of Research in E-learning, Vol. 2, No. 1, pp. 57-70.

Kuciński, K. (1990), Podstawy teorii regionu ekonomicznego, Państwowe Wydawnictwo Naukowe, Warszawa.

Locke, S.M., Bracey, G., Foster, T., Fraine, S., Hu, S., Lacombe, K., and Wilson, C. (2018), "Connecting formal and informal learning to enhance elementary teacher preparation in geosciences", Terrae Didatica, Vol. 14, No. 3, pp. 282-288. doi: 10.20396/td.v14i3.8653527

Matherson, L., Wright, V.H., Inman, C.T. and Wilson, E.K. (2008), "Get up, Get out with Geocaching: Engaging Technology for the Social Studies Classroom”, Social Studies Research and Practice, Vol. 3, No. 3, pp. $80-85$

Middleton, A.C. (2011), "City Branding and Inward Investment", in Dinnie, K. City Branding. Theory and Cases, Palgrave Macmillan, London, pp. 15-26. doi:10.1057/9780230294790_3

Milewski, D. and Meyer, B. (Ed.) (2009), Strategie rozwoju turystyki w regionie, Wydawnictwo Naukowe PWN, Warszawa.

O’Hara, K. (2008), “Understanding geocaching practices and motivations", Conference: Proceedings of the 2008 Conference on Human Factors in Computing Systems, CHI 2008, pp. 1177-1186. doi:10.1145/1357054.1357239 
ToSEE - Tourism in Southern and Eastern Europe, Vol. 6, pp. 623-635, 2021.

E. Pisula: INFORMATIVE, EDUCATIONAL, AND PROMOTIONAL ROLE OF GEOCACHING ...

Neustaedter, C., Tang, A. and Judge, T.K. (2010), "The role of community and groupware in geocache creation and maintenance", Proceedings of the $28^{\text {th }}$ International Conference on Human Factors in Computing System. USA, pp.1757-1766.

Neustaedter, C., Tang, A. and Judge, T.K. (2013), “Creating scalable location-based games: lessons from Geocaching”, Personal and Ubiquitous Computing, Vol. 17, No. 2, pp. 335-349.

Rosario, I.T., Rebelo, R., Cardoso, P., Segurado, P. and Mendes, R.N. (2019), "Can geocaching be an indicator of cultural ecosystem services? The case of Montado Savannah-like landscape", Ecological Indicators, Vol. 99 (2019), pp. 375-386. doi: 10.1016/j.ecolind.2018.12.003

Rowland, M.J. (2016), "Geocaching and cultural heritage. The Artefact", The Journal of the Archaecological and Anthropological Society of Victoria, Vol. 36, pp. 3-9.

Santos, T., Mendes, R.N., Rodrigues, A.M. and Freire, S. (2012), "Treasure Hunting in the $21^{\text {st }}$ century: A Decade of Geocaching in Portugal". Conference: $6^{\text {th }}$ European Conference on Information Management and Evaluation-ECIME2012, Ireland, pp. 273-281.

Schaal, A. and Lude, A. (2015), "Using mobile devices in environmental education and education for sustainable development - comparing theory and practice in a National Wide Survey", Sustainability, Vol. 7, No. 8, pp. 10153-10170. https://doi.org/10.3390/su70810153

Schneider, E. and Chavez, D.J. (2010), "Geocaching: form, function and opportunity", Outdoor recreation trends and futures: a technical document supporting the Forest Service 2010 RPA Assessment. General Technical Reports. U.S. Department of Agriculture Forest Service, Southern Research Station, pp. 55-58

Schneider, I.E. and Chavez, D. (2011), “Geocachers: Benefits sought and environmental attitudes", LARNet, The Cyber Journal of Applied Leisure and Recreation Research, Vo.14, No. 1, pp. 1-11.

Sztumski, J. (1995), Wstep do metod i badań społecznych, Wydawnictwo „Śląsk”, Katowice.

Telaar, D., Krüger, A. and Schöning, J. (2014), "A large-scale Quantitative Survey of German Geocaching Community in 2007", Advances in Human-computer Interaction, Vol. 2014, No. 3, Hindawi Publishing Corporation, pp. 1-11. https://doi.org/10.1155/2014/257815

Szromnik, A. (2011), "Marketing terytorialny jako atrybut rynkowej orientacji miast oraz regionów", in Grzegorczyk, A. and Kochaniec, A. (Ed.) Kreowanie wizerunku miast, Wyższa Szkoła Promocji, Warszawa, pp. 18-41.

Ustawa o samorządzie województwa z dn. 5 czerwca 1998 r. (Dz.U. 2020 poz. 1668).

$\mathrm{Xu}$, F., Tian, F., Buhalis, D., Weber, J. and Zhang, H. (2016), "Tourists as Mobile Gamers: Gamification for Tourism Marketing", Journal of Travel and Tourism Marketing, Vol. 33, No. 8, pp. 1124-1142. https://doi.org/10.1080/10548408.2015.1093999

Ewa Pisula, PhD Student

The Poznan University of Economics and Business

Al. Niepodległości 10, Poland

61-875 Poznan

ewa.pisula.contact@gmail.com 